Jurnal Basicedu Volume 3 Nomor 4 Tahun 2019 Halaman 2016-2024

JURNAL BASICEDU

Research \& Learning in Elementary Education

https://jbasic.org/index.php/basicedu

\title{
PENGARUH PENGGUNAAN MODEL PROBLEM BASED LEARNING ( PBL) TERHADAP HASIL BELAJAR SISWA DI SEKOLAH DASAR
}

\author{
Aisyah Nofziarni ${ }^{1}$, Hadiyanto ${ }^{2}$, Yanti Fitria ${ }^{3}$, Alwen Bentri ${ }^{4}$ \\ Universitas Negeri Padang, Sumatera Barat, Indonesia ${ }^{1,2,3,4}$ \\ Email: Aisyahnofziarni1@gmail.com ${ }^{1}$, hadiyanto@fip.unp.ac.id ${ }^{2}$, vantifitria@ymail.com³ \\ alw3n b3ntri@yahoo.com ${ }^{4}$
}

\begin{abstract}
Abstrak
Penelitian ini dilatarbelakangi oleh pembelajaran belum dimulai dengan memberikan masalah yang autentik, sehingga apabila siswa dihadapi dengan suatu permasalahan siswa kurang mampu menyikapi dan menentukan solusi terhadap pemecahan masalah tersebut. Jenis penelitian adalah eksperimen semu (quasi experimen). Hasil penelitian menunjukkan bahwa terdapat pengaruh penggunaan model Problem Based Learning (PBL) terhadap hasil belajar pada materi mengidentifikasi sifat-sifat bangun ruang di kelas V SD Negeri 04 Garegeh. Hal ini dibuktikan dari hasil t-test dengan taraf signifikan 5\% $(0,05)$ diperoleh $\mathrm{t}$ hitung $(7,36)>\mathrm{t}$ tabel (1,6694). Dapat disimpulkan bahwa hasil belajar siswa di kelas eksperimen yang diajar menggunakan model Problem Based Learning (PBL) tergolong criteria sangat tinggi, dengan hasil belajar diperoleh skor maksimal adalah 100 dan skor minimal adalah 64 sedangkan nilai rata-rata kelas eksperimen adalah 82,30. Dengan demikian model Problem Based Learning (PBL) dapat mempengaruhi hasil belajar siswa di kelas
\end{abstract}

Kata Kunci: problem based learning, hasil belajar siswa

\begin{abstract}
Abstrack
This research is motivated by the learning has not yet begun to give an authentic problem, so that when students are faced with a problem of students are less able to respond and determine solutions to solving the problem. This type of research is quasi experiment(quasi experimental. The results showed that there are significant use of the model Problem Based Learning (PBL) on learning outcomes in the material identifying geometrical properties in the class V SD Negeri 04 Garegeh. This is evidenced from the t-test with significance level of 5\% (0.05) obtained by the $t$ (7,36)> t table (1.6694). Can be concluded that student learning outcome in the experimental class are taught using Problem Based Learning (PBL) models are classified as very high criteria, with learning outcomes obtained a maximum score of 100 and a score the minimum is 64 while the average value of the experimental class is 82,30. Thus the problem based learning $(P B L)$ model can affect student learning outcomes in class.
\end{abstract}

Keywords: problem-based learning,student learning outcomes

@ Jurnal Basicedu Prodi PGSD FIP UPTT 2019

Corresponding author:

Address :

ISSN 2580-3735 (Media Cetak)

Email :

ISSN 2580-1147 (Media Online)

Phone 
2017 Pengaruh penggunaan model PBL terhadap hasil belajar siswa di sekolah dasar- Aisyah Nofziarni, Hadiyanto, Yanti Fitria, Alwen Bentri

\section{PENDAHULUAN}

Model Problem based learning merupakan salah satu model pembelajaran yang memberikan siswa permasalahan-permasalahan yang berhubungan dengan kehidupan sehari-hari yang dapat membantu pemahaman siswa terhadap materi pembelajaran. Pada model ini masalah disajikan pada awal pembelajaran dan siswa diminta untuk memecahkan masalah tersebut.

Model Problem Based Learning (PBL) adalah pembelajaran yang dimulai dengan masalah autentik (nyata) yang sesuai dengan materi pelajaran sehingga dapat melatih siswa untuk berfikir secara kritis dalam memecahkan suatu permasalahan, serta dapat memupuk keterampilan siswa dalam memecahkan suatu permasalahan. Hal tersebut dijelaskan oleh Riyanto (2010:285) bahwa," Pembelajaran berdasarkan masalah adalah suatu model pembelajaran yang dirancang dan dikembangkan untuk mengembangkan kemampuan peserta didik memecahkan masalah".

Selain itu, model Problem Based Learning (PBL) juga menjadikan siswa lebih aktif karena pada proses pembelajaran siswa diberi kesempatan untuk mengembangkan kemampuan berfikirnya, mengarahkan siswa untuk mampu memecahkan masalah dalam bidang studi yang dipelajari, hal ini sesuai dengan pendapat Ngalimun (2016:117) bahwa "PBL adalah suatu model pembelajaran yang melibatkan siswa untuk memecahkan suatu masalah melalui tahap-tahap metode ilmiah sehingga siswa dapat mempelajari pengetahuan yang berhubungan dengan masalah tersebut dan sekaligus memiliki keterampilan untuk memecahkan masalah".

Masalah yang diberikan dalam model pembelajaran Problem Based Learning (PBL) adalah masalah yang sesuai dengan karakteristik siswa yaitu masalah yang sederhana dan tidak membutuhkan pemikiran yang sulit. Masalah ini digunakan sebagai pemicu bagi proses belajar siswa sebelum mengetahui konsep dari materi yang dipelajari. Sebagaimana menurut Hosnan (2014:298) "Model PBL menjadikan masalah sehari-hari sebagai pemicu bagi proses belajar siswa sebelum mereka mengetahui konsep formal".

Tujuan model Problem Based Learning (PBL) adalah untuk membantu siswa menjadi siswa yang lebih aktif dan selalu berfikir kritis dalam memecahkan masalah yang dihadapinya dalam pembelajaran. Sebagaimana menurut Hosnan (2014:298) "Tujuan Problem Based Learning adalah membantu siswa agar memperoleh berbagai pengalaman dan mengubah tingkah laku siswa, baik dari segi kualitas maupun kuantitas". Sedangkan menurut Fathurrohman (2015:113) “Tujuan utama Problem Based Learning bukanlah penyampaian sejumlah besar pengetahuan kepada peserta didik, melainkan berorientasi pada pengembangan kemampuan berpikir kritis dan kemampuan pemecahan masalah dan sekaligus mengembangkan kemampuan peserta didik untuk secara aktif membangun pengetahuan sendiri”.

Selain memiliki tujuan, model Problem Based Learning (PBL) juga memiliki beberapa keunggulan. Keunggulan Model Problem Based Learning (PBL) dapat dijadikan acuan dan alasan dalam penggunaan model Problem Based Learning (PBL) di setiap pembelajaran yang disesuaikan dengan materi yang diajarkan di SD.

Model Problem Based Learning (PBL) ini dapat digunakan guru dalam pembelajaran matematika di Sekolah Dasar khususnya pada materi mengidentifikasi sifat-sifat bangun ruang. Materi ini dipelajari di kelas $\mathrm{V}$ semester 2 yang terdapat dalam Kurikulum Tingkat Satuan Pendidikan (KTSP) dengan Standar Kompetensi (SK) 6. Memahami sifat-sifat bangun datar dan hubungan antar bangun, dan Kompetensi Dasar 
2018 Pengaruh penggunaan model PBL terhadap hasil belajar siswa di sekolah dasar- Aisyah Nofziarni, Hadiyanto, Yanti Fitria, Alwen Bentri

(KD) 6.2 Mengidentifikasi sifat-sifat bangun ruang.

Materi sifat-sifat bangun ruang merupakan materi yang menarik untuk dipelajari apabila disampaikan melalui proses pembelajaran yang benar. Akan tetapi, kesalahan dalam melaksanakan pembelajaran tentang materi sifat-sifat bangun ruang mengakibatkan siswa sulit menyelesaikan soal materi sifat-sifat bangun ruang tersebut. Siswa terkadang salah dalam menentukan antara sisi, rusuk, sudut maupun titik sudut.

Pada tanggal 15 Maret 2017, peneliti melakukan wawancara dengan guru kelas V SD Negeri 04 Garegeh Kota Bukittinggi. Berdasarkan hasil wawancara peneliti dengan guru kelas VA dan VB SD Negeri 04 Garegeh didapatkan bahwa selama pembelajaran mengenai mengidentifikasi sifat-sifat bangun ruang yang dilakukan, guru hanya menjelaskan materi sifat-sifat bangun ruang dan siswa menyimak materi yang dijelaskan oleh guru lalu siswa diminta mencatat sifat-sifat dari masing-masing bangun ruang tersebut ke dalam buku catatannya. Setelah itu guru memberikan latihan dan siswa bekerja sendiri-sendiri. Hal ini sejalan dengan pendapat Heruman (2010:109).

Oleh sebabitu, sebagian besar siswa mengalami kesulitan dalam memahami materi mengidentifikasi sifat-sifat bangun ruang. Apabila siswa ditanya mana yang disebut rusuk, sisi, dan titik sudut mereka sering terbolak balik menyebutkan antara sisi, rusuk dan titik sudut, selain itu minat dan motivasi siswa dalam belajar menjadi menurun sehingga berdampak pada rendahnya hasil belajar siswa.

Berdasarkan hasil observasi yang peneliti lakukan pada tanggal 27 Oktober 2016 di kelas VA dan 31 Oktober 2016 di kelas VB SD Negeri 04 Garegeh Kota Bukittinggi menunjukkan bahwa pada saat memulai pembelajaran guru belum mengaitkan materi dengan permasalahan seharihari, pembelajaran yang dilakukan guru yaitu dengan cara langsung menjelaskan materi yang akan dipelajari sehingga siswa dipaksa untuk menerima penjelasan dari guru tanpa membuktikan atau membangun sendiri konsep dalam pikiran siswa sehingga siswa menjadi bosan dan belum dapat mengaplikasikannya dalam kehidupan sehari-hari. Pembelajaran lebih banyak didominasi oleh guru sehingga siswa kurang memiliki kesempatan untuk mengembangkan kemampuan berfikirnya, akibatnya siswa kurang tertarik untuk mengikuti pembelajaran. Guru belum memberikan kesempatan kepada siswa untuk mengemukakan pendapatnya tentang materi yang dipelajarinya. Guru belum pernah mengetahui dan menggunakan model Problem Based Learning (PBL) pada proses pembelajaran.

Tujuan penelitian ini adalah untuk mengetahui Pengaruh Penggunaan Model Problem Based Learning (PBL) terhadap Hasil Belajar Siswa pada Materi Mengidentifikasi Sifat-sifat Bangun Ruang Di Kelas V SD Negeri 04 Garegeh Kota Bukittinggi.

\section{METODE}

Penelitian ini dilaksanakan pada semester II tahun pelajaran 2016/2017 di kelas V SD Negeri 04 Garegeh Kota Bukittinggi. Pada dasarnya penelitian itu bertujuan untuk mengetahui pengaruh penggunaan model Problem Based Learning terhadap hasil belajar siswa pada materi mengidentifikasi sifat-sifat bangun ruang di kelas $\mathrm{V}$ semester II, dengan variable bebas yaitu model Problem Based Learning, dan variable terikatnya yaitu hasil belajar siswa pada maateri sifat-sifat bangun ruang di kelas V semester II di Sekolah Dasar Negeri 04 Garegeh Kota Bukittinggi Tahun Ajaran 2016/2017. Penelitian ini dilakukan oleh peneliti langsung dalam mengajar baik di kelas kontrol dan juga di kelas eksperimen. Penelitian ini tergolong eksperimen semu (quasi experiment) dengan rancangan kelas eksperimen dan kelas 
2019 Pengaruh penggunaan model PBL terhadap hasil belajar siswa di sekolah dasar-Aisyah Nofziarni, Hadiyanto, Yanti Fitria, Alwen Bentri

control diberikan pre-test dan post-tes. Desain penelitian yang digunakan dalam penelitian ini yaitu rancangan Non-equivalent Control Group Design.

Pembelajaran yang digunakan sebagai perlakuan dalam hal ini dibedakan atas model Problem based Learning untuk kelompok eksperimen dan pembelajaran biasa tanpa perlakuan untuk kelompok kontrol.

Prosedur penelitian yang digunakan adalah (1) tahapan persiapan eksperimen, langkahlangkah yang dilakukan yaitu: (a) menyusun intrumen penelitian berupa tes hasil belajar pada jenis kognitif untuk mengukur hasil belajar siswa pada materi mengidentifikasi sifat-sifat bangun ruang. (b) mengadakan validasi intrumen penelitianya itu tes hasil belajar mengidentifikasi sifat-sifat bangun ruang. (2) tahapan pelaksanaan eksperimen, langkah-langkah yang dilakukan yaitu: (a) menentukan sampel penelitian berupa kelas dari populasi yang tersedia; (b) dari sampel yang telah diambil kemudian diacak untuk menentukan kelas eksperimen dan kelas kontrol; (c) melaksanakan penelitian tersebut dengan memberikan perlakuan kepada kelas eksperimen berupa model Problem Based Learning dan kelas control berupa pembelajaran biasa (tradisional) (3) tahapan pengakhiran eksperimen, langkah selanjutnya yang dilakukan adalah memberikan post-test pada akhir penelitian, baik untuk kelompok eksperimen maupun kelompok kontrol.

Pengumpulan data hasil belajar dalam penelitian ini menggunakan metodetes. Yang merupakan alat untuk mengukur hasil belajar mengidentifikasi sifat-sifat bangun ruang.

Populasi penelitian ini adalah siswa kelas VSD Negeri 04 Garegeh Kota Bukittinggi. Siswa kelas V SDN 04 Garegeh ini memiliki kelas rangkap yaitu kelas VA dan VB. Untuk menentukan sample digunakan teknik purposive sampling dan penentuan kelas eksperimen dan kelas control dipilih secara acak. Dimana terpilih kelas VA sebagai kelas eksperimen dan kelas VB sebagai kelas kontrol.

Dalam penelitian ini terdapat dua variabel yang terdiri atas variable bebas dan variable terikat. Variabel bebas yang dimaksud dalam penelitian ini yaitu model Problem Based Learning pada kelas eksperimen dan pembelajaran biasa tanpa perlakuan pada kelas kontrol. Variabel terikat dalam penelitian ini adalah Hasil Belajar Siswa Pada Materi Mengidentikasi Sifat-sifat Bangu Ruang.

Data yang diperlukan adalah data tentang hasil belajar siswa pada materi Mengidentifikasi Sifat-sifat Bangun Ruang dikelas V di Sekolah Dasar Negeri 04 Garegeh. Untuk mengumpulkan data digunakan tes hasil belajar mengidentifikasi sifat-sifat bangun ruang, instrument yang digunakan yaitu tes objektif dalam bentuk pilihan ganda sebanyak 25 soal. Tes hasil belajar mengidentifikasi sifat-sifat bangun ruang disusun oleh peneliti dan guru kelas $\mathrm{V}$ melalui bimbingan dosen pembimbing. Setelah tes disusun,terlebih dahulu diuji validitas, daya pembeda, tingkat kesukaran, dan reliabilitasnya.Berdasarkan hasil uji validitas dan daya pembeda, diperoleh 25 soal yang valid dan 5 soal tidak valid.

Kemudian 25 soal dianalisis tingkat kesukarannya. Setelah diuji tingkat kesukarannya, selanjutnya 25 soal diuji reliabilitasnya dengan menggunakan rumus KR-21. Uji reliabilitas 25 soal diperoleh r11 =0,89 tes memiliki reliabilitas yang tinggi.

Data hasil belajar siswa pada materi mengidentifikasi sifat-sifat bangun ruang yang telah terkumpul, kemudian dianalisi menggunakan statistik uji-t. Sebelum dilakukan analisis data terlebih dahulu dilakukan uji prasyarat analisis yaitu uji normalitas sebaran data dan uji homogenitas varians. 
2020 Pengaruh penggunaan model PBL terhadap hasil belajar siswa di sekolah dasar- Aisyah Nofziarni, Hadiyanto, Yanti Fitria, Alwen Bentri

Uji Normalitas sebaran data hasil belajar siswa pada materi mengidentifikasi sifat-sifat bangun ruang digunakan analisis Liliefors. Untuk menguji homogenitas varians diuji dengan menggunakan uji F. Apabila F hitung $\geq \mathrm{F}$ table maka kedua populasi memiliki varians yang berbeda (tidak homogen), Jika $\mathrm{F}$ hitung $<\mathrm{F}$ table maka kedua populasi memiliki varians yang homogen. Pengujian dilakukan pada taraf signifikansi $5 \%$ dengan derajat kebebasan untuk pembilang n1-1, derajat kebebasan untuk penyebut n2-1.

Setelah pengujian normalitas dan homogenitas data dilakukan, maka hasil pengujian dari normalitas dan homogenitas data tersebut digunakan dalam menentukan pemilihan statistik uji yang akan digunakan pada pengujian hipotesis penelitian. Rata-rata skor dalam hasil belajar antara kelas yang dibelajarkan dengan menggunakan model problem based learning dengan kelas yang dibelajarkan menggunakan pembelajaran biasa tanpa perlakuan diuji dengan menggunakan statistik uji $t$.

Adapun hipotesis statistic dalam penelitian ini yaitu dapat dijelaskan sebagai berikut:

Ho $=$ Tidak terdapat pengaruh penggunaan model Problem Based Learning (PBL) terhadap hasil belajar siswa pada materi mengidentifikasi sifatsifat bangun ruang di kelas V SDN 04 Garegeh.

$\mathrm{H}_{1}=$ Terdapat pengaruh penggunaan model Problem Based Learning (PBL) terhadap hasil belajar siswa pada materi mengidentifikasi sifat-sifat bangun ruang di kelas V SDN 04 Garegeh.

\section{HASIL DAN PEMBAHASAN}

Pretest kelompok eksperimen kelas VA SDN 04 Garegeh pada harisabtu, 29 april 2017 pada jam pelajaran pertama. Siswa yang mengikuti pretest berjumlah 33 orang.
Tabel 1.

Data Hasil Pretes Kelompok Eksperimen

\begin{tabular}{|l|l|}
\hline N & 33 \\
\hline Maks & 76 \\
\hline Min & 28 \\
\hline Jumlah skor & 1688 \\
\hline Rata-rata & 51,15 \\
\hline Median & 52 \\
\hline Modus & 60 \\
\hline SD & 14,68 \\
\hline
\end{tabular}

Dari tabel di atas diperoleh nilai tertinggiyaitu 76 , nilai terendah 28 , nilai rata-rata 51,15, median yaitu 52 dan modus yaitu 62 .

Pretest kelompok control kelas VB SDN 04 Garegeh pada hari sabtu, 29 april 2017 pada jam pelajaran kedua. Siswa yang mengikuti pretest berjumlah 32 orang.

\section{Tabel 2}

\section{Data Hasil Pretes Kelompok Kontrol}

\begin{tabular}{|l|l|}
\hline $\mathbf{N}$ & 32 \\
\hline Maks & 80 \\
\hline Min & 28 \\
\hline Jumlahskor & 1636 \\
\hline Rata-rata & 53 \\
\hline Median & 52 \\
\hline Modus & 60 \\
\hline & 13,96 \\
\hline
\end{tabular}

Dari tabel di atas diperoleh nilai tertinggi yaitu 80 , nilai terendah 28 , nilai rata-rata 53, median yaitu 52 dan modus yaitu 60 .

Data nilai rata-rata yang diperoleh kelompok eksperimen adalah 51,15 dan nilai rata-rata kelompok control adalah 53. Berdasarkan nilai capaian tersebut, maka dapat dikategorisasikan sebagai nilai rata-rata pretes kelompok eksperimen sebesar 51,15 termasuk criteria kurang. Sedangkan nilai rata-rata kelompok control sebesar 53 dalam kategori kurang. Nilai yang diperoleh kedua kelompok relative sama.

Postes untuk kelompok eksperimen dilaksanakan pada hari sabtu, 06 mei 2017 pada jam ke 1 dan 2. Siswa yang mengikuti postes berjumlah 33 siswa. 
2021 Pengaruh penggunaan model PBL terhadap hasil belajar siswa di sekolah dasar- Aisyah Nofziarni, Hadiyanto, Yanti Fitria, Alwen Bentri

Tabel 3

Data Hasil Postes Kelompok Eksperimen

\begin{tabular}{|l|l|}
\hline N & 33 \\
\hline Maks & 100 \\
\hline Min & 64 \\
\hline Jumlahskor & 2716 \\
\hline Rata-rata & 82,30 \\
\hline Median & 80 \\
\hline Modus & 80 \\
\hline
\end{tabular}

Dari tabel di atas diperoleh nilai tertinggi yaitu 100 , nilai terendah 64 , nilai rata-rata 82,30 , median yaitu 80 dan modus yaitu 80 .

Postes untuk kelompok control dilaksanakan pada hari sabtu, 06 mei 2017 pada jam ke 3 dan 4 . Siswa yang mengikuti postes berjumlah 32 siswa.

Tabel 4.

Data Hasil Postes Kelompok Kontrol

\begin{tabular}{|l|l|}
\hline N & 32 \\
\hline Maks & 92 \\
\hline Min & 60 \\
\hline Jumlahskor & 2452 \\
\hline Rata-rata & 76,63 \\
\hline Median & 76 \\
\hline Modus & 84 \\
\hline
\end{tabular}

Dari tabel di atas diperoleh nilai tertinggi yaitu 92, nilai terendah 60 , nilai rata-rata 76,63 , median yaitu 76 dan modus yaitu 84 .

Nilai rata-rata pretes kelompok eksperimen sebesar 51,15 dan rata-rata pretes kelompok control sebesar 53,00. Sedangkan nilai postes kelompok eksperimen sebesar 82,30 dan nilai postes kelompok control sebesar 76,63. Perbandingan nilai pretes dan postes antara kelompok kontrol dan kelompok eksperimen dapat dilihat pada table dibawah ini .

\section{Tabel 5}

Perbandingan nilai pretes dan postes kelompok

\begin{tabular}{|c|c|c|c|c|}
\hline \multirow{3}{*}{$\begin{array}{l}\mathbf{N} \\
\mathbf{0}\end{array}$} & \multirow{3}{*}{$\begin{array}{l}\text { Kelomp } \\
\text { ok }\end{array}$} & \multirow{2}{*}{\multicolumn{2}{|c|}{ Nilai rata- }} & \multirow{3}{*}{$\begin{array}{l}\text { Peningka } \\
\text { tan }\end{array}$} \\
\hline & & & & \\
\hline & & Pret & Post & \\
\hline 1. & Eksperi & 51,1 & 82,3 & 31,15 \\
\hline 2. & Kontrol & 53,0 & 76,6 & 23,63 \\
\hline
\end{tabular}

Sebelum melakukan uji hipotesis menggunakan rumus t-test terlebih dahulu dilakukan uji normalitas dan uji homogenitas variansi.

Untuk melakukan uji normalitas dari data tes pretest baik pada kelas eksperimen maupun kelas kontrol digunakan uji Lilliefors. Setelah dilakukan perhitungan data pada kedua kelas sampel, maka diperoleh harga $\mathrm{L}_{\mathrm{o}}$ dan $\mathrm{L}_{(\mathrm{n}, \mathrm{a})}$ dengan taraf nyata 0,05 sebagai berikut :

\section{Tabel 6}

Hasil Uji Normalitas Data Pretest Kelas Sampel

\begin{tabular}{|c|c|c|c|c|c|}
\hline Kela & $\mathbf{N}$ & $\mathbf{L}_{0}$ & $\mathbf{L}_{\mathbf{t}}$ & Kesi & Kete \\
\hline Eksp & 3 & 0.1 & 0.2 & $\mathrm{~L}_{\mathrm{O}}$ & Data \\
\hline Kont & 3 & $\begin{array}{l}110 \\
0.1\end{array}$ & 0.2 & $\begin{array}{l}\mathrm{L}_{\mathrm{O}} \\
\mathrm{L}\end{array}$ & Data \\
\hline
\end{tabular}

Dari tabel 16 di atas dapat diketahui bahwa untuk kedua kelas sampel harga $\mathrm{Lo}_{\mathrm{O}}$ $<\mathrm{L}_{(\mathrm{n}, \mathrm{a})}$, dengan demikian dapat disimpulkan bahwa data pretest kedua kelas sampel berdistribusi normal pada tingkat kepercayaan $95 \%$.

Uji homogenitas variansi bertujuan untuk melihat data hasil pretest kelas eksperimen dan kelas control mempunyai variansi yang homogeny atau tidak.Dalam uji homogenitas digunakan uji F.

Setelah dilakukan perhitungan, diperoleh data dari kedua kelas sampel sebagai berikut:

$\mathrm{F}=\frac{\text { Varians terbesar }}{\text { variansi terkecil }}$

Perhitungan harga $\mathrm{F}$ dengan taraf nyata $\alpha=$ 0,05 dari table distribusi $\mathrm{F}$, ternyata diperoleh harga yaituF $F_{\text {hitung }}<F_{\text {tabel }} 1,1058<1,8346$. Dapat disimpulkan bahwa data hasil pretest kedua kelas sampel memiliki variansi yang homogen pada tingkat kepercayaan $95 \%$. 
2022 Pengaruh penggunaan model PBL terhadap hasil belajar siswa di sekolah dasar- Aisyah Nofziarni, Hadiyanto, Yanti Fitria, Alwen Bentri

Pengujian hipotesis dilakukan uji normalitas dan uji homogenitas variansi diketahui bahwa kedua kelas sampel memiliki data hasil pretes berdistribusi normal dan variansi yang homogen, maka untuk menguji hipotesis digunakan rumus ttes. Sebelum dilakukan uji $\mathrm{t}$ terlebih dahulu dihitung harga simpangan baku gabungan dari data kedua kelompok sampel, yaitu Dari daftar distribusi $\mathrm{t}$ dengan taraf nyata $0,05 \mathrm{dan} \mathrm{dk}=63$, diperoleh $\mathrm{t}_{(0,05 ; 63)}=1,6694$ sedangkan $\mathrm{t}_{\text {hitung }}=$ 2,45. Hal ini berartit ${ }_{\text {hitung }}<\mathrm{t}_{\text {tabel, }} \quad-2,45<1,6694$ sehingga Ho diterima dan $\mathrm{H}_{1}$ ditolak. Jadi hipotesis ditolak.

Setelah dilakukan perhitungan data pada kedua kelas sampel, maka diperoleh harga $\mathrm{L}_{\mathrm{o}}$ dan $\mathrm{L}_{(\mathrm{n}, \mathrm{a})}$ dengan taraf nyata 0,05 sebagai berikut :

\section{Tabel 6}

. Hasil Uji Normalitas DataTes Hasil Belajar (Postest) Siswa Kelas Sampel

\begin{tabular}{|l|l|l|l|l|l|}
\hline Kela & $\mathbf{N}$ & $\mathbf{L}_{\mathbf{o}}$ & $\mathbf{L}_{\mathbf{t}}$ & Kesi & Kete \\
\hline Eksp & 3 & 0.1 & 0.2 & $\mathrm{~L}_{\mathrm{O}}$ & Data \\
\hline Kont & 3 & 0.0 & 0.2 & $\mathrm{~L}_{\mathrm{O}}$ & Data \\
\hline
\end{tabular}

Dari tabel 7 di atas dapat diketahui bahwa untuk kedua kelas sampel harga $\mathrm{L}_{\mathrm{O}}<\mathrm{L}_{(\mathrm{n}, \mathrm{a})}$, dengan demikian dapat disimpulkan bahwa data tes hasil belajar kedua kelas sampel berdistribusi normal pada tingkat kepercayaan $95 \%$.

Setelah dilakukan perhitungan, diperoleh data dari kedua kelas sampel sebagai berikut:

$\mathrm{F}=\frac{\text { Varians terbesar }}{\text { variansi terkecil }}$

Perhitungan harga $\mathrm{F}$ dengan taraf nyata $\alpha=$ 0,05 dari table distribusi $\mathrm{F}$, ternyata diperoleh harga yaitu $\mathrm{F}_{\text {hitung }}<\mathrm{F}_{\text {tabel }} 1.4037<1.8346$. Dapat disimpulkan bahwa data hasil tes akhir kedua kelas sampel memiliki variansi yang homogen pada tingkat kepercayaan $95 \%$.

Dari daftar distribusi $t$ dengan taraf nyata 0,05 dan $\mathrm{dk}=63$, diperoleh $\mathrm{t}_{(0,05 ; 63)}=1,6694$ sedangkan $\mathrm{t}_{\text {hitung }}=7,36$
Berdasarkan perhitungan di atas ternyata $\mathrm{t}_{\text {hitung }}>\mathrm{t}_{(\alpha, \mathrm{dk})}$, berarti hipotesis $\mathrm{H}_{\mathrm{O}}$ ditolak $\mathrm{H}_{1}$ diterima. Dapat disimpulkan bahwa terdapat pengaruh penggunaan model Problem Based Learning (PBL) terhadap hasil belajar siswa pada materi mengidentifikasi sifat-sifat bangun ruang di kelas V SDN 04 Garegeh Kota Bukittinggi.

Selanjutnya akan dilakukan perbandingan antara nilai pre-test dan post-test, yang tujuannya untuk melihat apakah ada perbedaan nilai pre-test dan post-test siswa.

Tabel 7

Perbandingan Hasil Perhitungan Nilai Pre-test dan Post-test

\begin{tabular}{|l|l|l|l|l|}
\hline \multirow{2}{*}{ Variabel } & \multicolumn{2}{|l|}{ Pre-test } & \multicolumn{2}{l|}{ Post-test } \\
\cline { 2 - 5 } & $\begin{array}{l}\text { Ekspe } \\
\text { rimen }\end{array}$ & $\begin{array}{l}\text { Kontr } \\
\text { ol }\end{array}$ & $\begin{array}{l}\text { Ekspe } \\
\text { rimen }\end{array}$ & $\begin{array}{l}\text { Kon } \\
\text { trol }\end{array}$ \\
\hline $\begin{array}{l}\text { Nilai } \\
\text { tertinggi }\end{array}$ & 76 & 80 & 100 & 92 \\
\hline $\begin{array}{l}\text { Nilai } \\
\text { terendah }\end{array}$ & 28 & 28 & 64 & 60 \\
\hline Rata-rata & 51,15 & 53,00 & 82,30 & 76,6 \\
\hline
\end{tabular}

Berdasarkan tabel dan di atas, uji hipotesis nilai pre-test $t_{\text {hitung }}$ lebih kecil dari pada tabel($\mathbf{2 , 4 5}<\mathbf{1 , 6 6 9 4}$ ), sedangkan uji hipotesis nilai postest $\mathrm{t}_{\text {hitung }}$ lebih besar dari pada $\mathrm{t}_{\text {tabel }}(\mathbf{7}, 36>1,6694)$. Jadi dapat disimpulkan bahwa terdapat perbedaan yang signifikan antara nilai pre-test dan nilai posttest hasil belajar siswa pada materi mengidentifikasi sifat-sifat bangun ruang.

Berdasarkan hasil pre-test materi mengidentifikasi sifat-sifat bangun ruang siswa pada kelompok eksperimen dan kelompok kontrol pada pre-test diperoleh angka rata-rata kelompok eksperimen yaitu 51,15. Angka rata-rata kelompok control yaitu 53,00. Berdasarkan hasil analisis data yang telah dilakukan bahwa thitung sebesar-2,45 dibandingkan dengan $\alpha 0,05\left(\mathrm{t}_{\text {tabel }}=1,6694\right)$ dengan derajat kebebasan $\mathrm{dk}\left(\mathrm{N}_{1}-1\right)+\left(\mathrm{N}_{2}-1\right)=63$. Dengan 
2023 Pengaruh penggunaan model PBL terhadap hasil belajar siswa di sekolah dasar- Aisyah Nofziarni, Hadiyanto, Yanti Fitria, Alwen Bentri

demikian $\mathrm{t}_{\text {hitung }}<\mathrm{t}_{\text {tabel }}$ yaitu $-2,45<1,6694$, maka dapat dikatakan bahwa hipotesis $\mathrm{H}_{\mathrm{o}}$ diterima atau $\mathrm{H}_{1}$ ditolak.

Jadi dapat disimpulkan bahwa tidak terdapat pengaruh penggunaan model problem based learning (PBL) terhadap hasil belajar siswa pada materi mengidentifikasi sifat-sifat bangun ruang siswa pada materi mengidentifikasi sifat-sifat bangun ruang di kelas V SD Negeri 04 Garegeh. Ini berarti hasil belajar siswa pada tes kemampuan awal (pre-test) sama atau tidak memiliki pengaruh yang signifikan.

Selanjutnya diberikan treatment (perlakuan) pada masing-masing kelas. Kemudian dilakukan post-test. Berdasarkan hasil belajar siswa pada materi mengidentifikasi sifat-sifat bangun ruang yang diberikan pada kelas eksperimen dan kelas kontrol pada tahap post-test diperoleh angka ratarata kelompok eksperimen yaitu 82,18 dan angka rata-rata kelompok control yaitu 76,62.

Berdasarkan hasil analisis data yang telah dilakukan bahwa thitung sebesar 7,36 dibandingkan dengan $\alpha 0,05 \quad\left(t_{\text {tabel }}=1,6694\right)$ dengan derajat kebebasan dk $\left(\mathrm{N}_{1}-1\right)+\left(\mathrm{N}_{2}-1\right)=63$. Dengan demikian $\mathrm{t}_{\text {hitung }}>\mathrm{t}_{\text {tabel }}$ yaitu $7,36>1,6694$, maka dapat dikatakan bahwa hipotesis $H_{I}$ diterima atau $H_{o}$ ditolak. Dari hasil tersebut terlihat bahwa terdapat pengaruh penggunaan model problem based learning (PBL) terhadap hasil belajar siswa pada materi mengidentifikasi sifat-sifat bangun ruang di kelas V SD Negeri 04 Garegeh. Berdasarkan penelitian yang peneliti lakukan terlihat hubungan hasil pre-test dan post-test. Hasil pre-test terlihat bahwa rata-rata kelas eksperimen yaitu 51,15 dan rata-rata kelas control yaitu 53,00. Setelah diberikan treatment terlihat hasil post-test siswa pada materi mengidentifikasi sifat-sifat bangun ruang pada kelas eksperimen menggunakan model Problem Based Learning (PBL)lebih meningkat dengan rata-rata 82,18 , sedangkan pada kelas control menggunakan pembelajaran biasa tanpa perlakuan dengan rata- rata 76,62. Dengan demikian dapat disimpulkan bahwa terdapat perbandingan hasil pre-test dan hasil post-test siswa pada materi mengidentifikasi sifat-sifat bangun ruang kelompok eksperimen dan kelompok kontrol. Jadi, dapat disimpulkan bahwa terdapat pengaruh penggunaan model Problem Based Learning (PBL) terhadap hasil belajar siswa pada materi mengidentifikasi sifat-sifat bangun ruang di kelas V SD Negeri 04 Garegeh Kota Bukittinggi.

Jadi, hasil belajar siswa di kelas eksperimen lebih baik dari pada hasil belajar siswa di kelas kontrol, dapat dilihat dari rata-rata siswa kelas eksperimen yang lebih tinggi dari pada kelas kontrol. Maka dapat disimpulkan bahwa penggunaan model Problem Based Learning (PBL) mempengaruhi hasil belajar siswa pada materi mengidentifikasi sifat-sifat bangun ruang.

\section{SIMPULAN}

Berdasarkan hasil penelitian yang telah dikemukakan pada BAB IV dapat disimpulkan bahwa hasil belajar siswa di kelas eksperimen yang diajar menggunakan model Problem Based Learning (PBL) tergolong criteria sangat tinggi, dengan hasil belajar diperoleh skor maksimal adalah 100 dan skor minimal adalah 64 sedangkan nilai rata-rata kelas eksperimen adalah 82,30. Dengan demikian model Problem Based Learning(PBL) dapat mempengaruhi hasil belajar siswa di kelas.

Berdasarkan kesimpulan di atas dapat dikemukakan beberapa saran untuk perbaikan hasil pembelajaran, antara lain Bagi guru agar dapat menggunakan model Problem Based Learning(PBL) dalam proses pembelajaran mengidentifikasi sifat-sifat bangun ruang di SD, karena penerapan model Problem Based Learning(PBL) dapat meningkatkan hasil belajar siswa. Penelitian ini hanya meneliti hasil belajar siswa menggunakan model Problem 
2024 Pengaruh penggunaan model PBL terhadap hasil belajar siswa di sekolah dasar- Aisyah Nofziarni, Hadiyanto, Yanti Fitria, Alwen Bentri

Based Learning(PBL) dan pembelajaran biasa

dilakukan guru. Untuk itu, disarankan pada peneliti selanjutnya untuk meneliti aspekaspek lainnya

\section{DAFTAR PUSTAKA}

Riyanto, Yatim. 2010. Paradigma Baru Pembelajaran sebagai Referensi bagi Guru/Pendidik dalam Implementasi Pembelajaran yang Efektif dan Berkualitas.Jakarta: Kencana Prenada Media Group

Ngalimun. 2016. Strategi dan Model Pembelajaran. Yogyakarta: Aswaja Pressindo

Hosnan, M. 2014. Pendekatan Saintifik dan Kontekstual dalam Pembelajaran Abad 21. Bogor: Ghalia Indonesia

Fathurrohman, Muhammad. 2015. Model-model Pembelajaran Inovatif. Jogyakarta:Ar-Ruzz Media 